\title{
Management of patients with congenital hypothyroidism
}

\author{
G J FROST, J M PARKIN
}

\begin{abstract}
The biochemical state and treatment of 73 children and 44 adults up to the age of 40 with proved congenital hypothyroidism were assessed in a regional study in the north of England. The findings showed that a substantial proportion of the patients were having inappropriate treatment or were not taking their treatment regularly and that in some of these there were clinical effects.
\end{abstract}

\section{Introduction}

The development of children with congenital hypothyroidism has been considerably improved as a result of early detection by neonatal screening. ${ }^{1}$ Nevertheless, satisfactory long term results also require optimal treatment. We have assessed the adequacy of treatment of patients with congenital hypothyroidism below the age of 40 in the north of England.

\section{Patients and methods}

All patients under 40 with a clinical onset of hypothyroidism before the age of 10 years in the Northern region were identified through the hospital and community services and general practitioners. There were 73 children ( 49 girls and 24 boys) and 44 adults ( 30 women and 14 men). The median age of the children was 8.4 years (range $1.6-15.9$ years) and their median age at diagnosis 0.8 year $(0 \cdot 1-13 \cdot 2$ years $)$. The median age of the adults at assessment was $22 \cdot 9$ years (range $16 \cdot 4-36.7$ years), and their median age at diagnosis was $0 \cdot 4$ year $(0 \cdot 1-15 \cdot 1$ years). Two children and one adult had

Royal Victoria Infirmary, Newcastle upon Tyne

G J FROST, MRCP, research registrar

J M PARKIN, FRCP, reader in paediatrics

Correspondence to: Dr G J Frost, Child Health Department, Ninewells Hospital and Medical School, Dundee DD1 9SY. confirmed dyshormonogenesis; the remainder were presumed to have other developmental anomalies of the thyroid gland.

The table gives the laboratory evidence confirming the diagnosis. Four other children and 17 other adults with adequate diagnostic criteria were either untraceable or not available for assessment. All the children were treated by paediatricians $(n=21) ; 20$ of the adults were treated by medical specialists and 24 by general practitioners. Each patient was seen in the study either at their local hospital or at home by one of us (GJF).

Criteria for diagnosis of hypothyroidism

\begin{tabular}{ccccc}
\hline $\begin{array}{c}\text { Abnormal } \\
\text { biochemistry }\end{array}$ & $\begin{array}{c}\text { Decreased radioiodine uptake } \\
<20 \%\end{array}$ & $\begin{array}{c}\text { Retarded } \\
\text { bone age }\end{array}$ & $\begin{array}{c}\text { No of } \\
\text { children }\end{array}$ & $\begin{array}{c}\text { No of } \\
\text { adults }\end{array}$ \\
\hline+ & + & + & 19 & 12 \\
+ & - & - & 10 & 10 \\
+ & - & + & 38 & 10 \\
+ & + & + & 4 & 5 \\
- & + & & 2 & 7 \\
\hline
\end{tabular}

Single serum thyroxine (T4), triiodothyronine (T3), and thyroid stimulating hormone (TSH) concentrations were obtained in most children and adults. T4 was measured using the Mallinckrodt radioimmunoassay diagnostic kit and TSH by a radioimmunoassay technique with MRC standard 68/38. ${ }^{2}$ The T3 method used double antibody radioimmunoassay. A T3/T4 index was calculated as the ratio of T3:T4 $\times 10^{3}$. Serum was examined for thyroid antibodies to exclude autoimmune thyroiditis.

Previous thyroid biochemical estimations were documented from the notes. The initial and subsequent treatment doses of the children were noted and compared with recent recommendations for the treatment of patients with congenital hypothyroidism ${ }^{3}$ (see appendix). The present treatment was expressed as total dose of thyroxine, dose of thyroxine per kilogram body weight, and dose of thyroxine per square metre of surface area and was related to the biochemical results. Patient compliance with treatment was assessed by a simple questionnaire given to the parents and to the adult patients.

Symptoms and signs including bowel disturbance, abnormal appetite, excessive weight gain, excessive energy, fatigue, acroparaesthesiae, palpitations, difficulty with concentration, voice change, dryness of skin and hair, and excessive sweating were determined at assessment and related to the biochemical state of each patient. The teeth were examined for evidence of enamel hypoplasia. 
All the patients were measured by the Harpenden Stadiometer with the exception of 15 children who were measured at home with a portable wall measure. Some parental heights were similarly measured (many were determined by history alone) and a midparental height centile estimated. Height standard deviation score and expected adult height (calculated from the midparental centile for the appropriate $\operatorname{sex}^{4}$ ) were determined for each child. Predicted adult height was calculated from measurements of height and bone age. ${ }^{5}$ Skinfold centiles and head circumference centiles were also recorded. ${ }^{67}$ The frequencies of previous outpatient growth measurements were noted from the clinical records. Bone age was measured using the RUS score ${ }^{5}$ in 67 children.

\section{Results}

\section{CHILDREN}

\section{Biochemical}

T4 was measured in 69 children, in whom the mean value was 155.8 $(51 \cdot 1) \mathrm{nmol} / \mathrm{l}(12 \cdot 1(4 \cdot 0) \mu \mathrm{g} / 100 \mathrm{ml})$. Figure 1 shows the individual results related to the normal reference ranges for age for the laboratory. There were no differences with sex. Only one of the T4 concentrations was below the normal range, but $27(39 \%)$ were at or above the upper reference limit. In 67 children both serum T4 and TSH concentrations were available. The $15(22 \%)$ children with a TSH concentration of $\geqslant 6 \mathrm{mU} / 1$ were over 5 years of age and only one had been diagnosed within two years of assessment. The mean T4 value of those with a raised TSH concentration was $109 \cdot 7$ $(33.6) \mathrm{nmol} / \mathrm{l}(8.5(2.6) \mu \mathrm{g} / 100 \mathrm{ml})$ and of those with a normal TSH concentration $168.0(48.4) \mathrm{nmol} / \mathrm{l}(13.1(3.8) \mu \mathrm{g} / 100 \mathrm{ml})(\mathrm{p}<0.001)$.

T3 concentrations were estimated in 63 children. The mean was 2.4 $(0.7) \mathrm{nmol} / \mathrm{l}(1.6(0.5) \mathrm{ng} / \mathrm{ml})$ with no sex difference. There was a significant correlation between $T 3$ and $T 4$ values $(p<0 \cdot 001)$. Figure 2 shows the serum concentration of $\mathrm{T} 3$ related to $\mathrm{T} 4$ and the laboratory reference ranges for $\mathrm{T} 3$ for childhood. Only one child had a $\mathrm{T} 3$ concentration below the normal range and nine above it. Over half of the children with raised $\mathrm{T} 4$ concentrations, however, had T3 values within the normal range. The mean T3 concentration for children with normal TSH values $(n=48)$ was $2.6(0.7) \mathrm{nmol} / \mathrm{l}(1 \cdot 7(0.5) \mathrm{ng} / \mathrm{ml})$, and for those with TSH concentrations of $\geqslant 6 \mathrm{mU} / \mathrm{l}(\mathrm{n}=14)$ the T3 value was $2.0(0.5) \mathrm{nmol} / \mathrm{l}(1.3(0.3) \mathrm{ng} / \mathrm{ml}$ $(p<0.005)$. Most of the children who had normal TSH concentrations had $\mathrm{T} 3$ and $\mathrm{T} 4$ values above the midpoint of the reference ranges.

Eighteen children (25\%) had had no previous biochemical monitoring, and only $39(53 \%)$ had had their TSH concentration measured previously

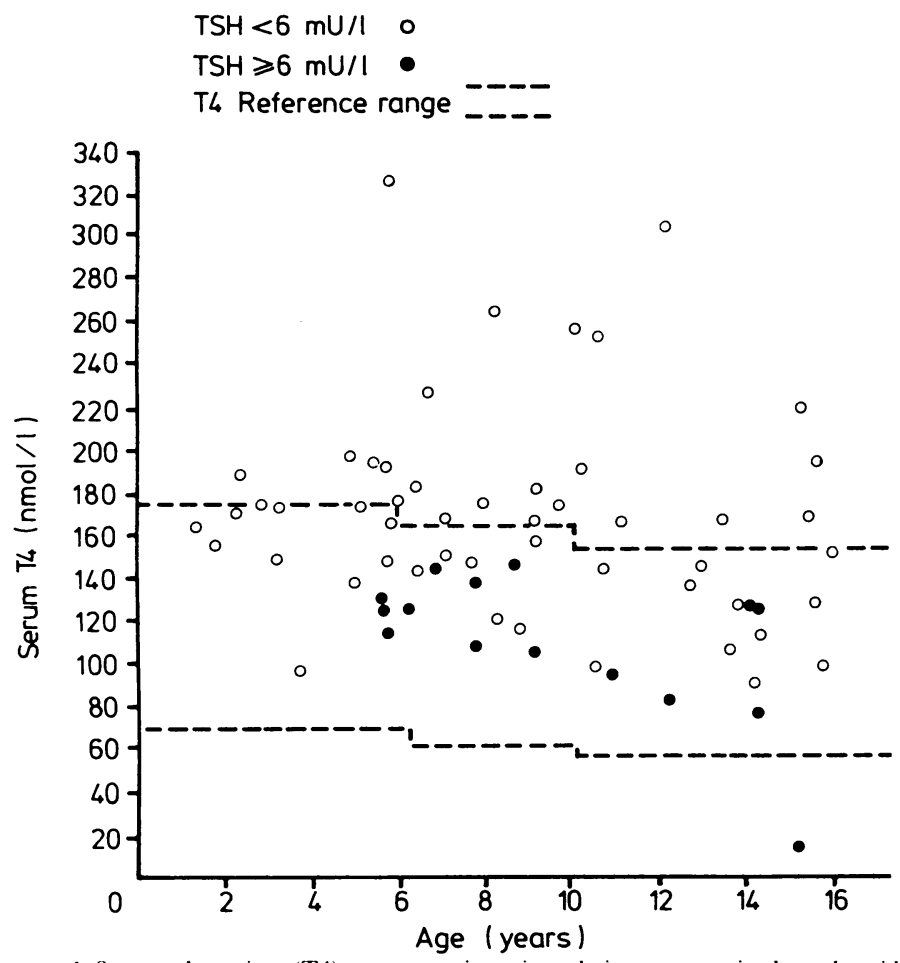

FIG 1-Serum thyroxine (T4) concentrations in relation to age in hypothyroid children.

Conversion: SI to traditional units-Thyroxine: $1 \mathrm{nmol} / \mathrm{l} \approx 0.08 \mu \mathrm{g} / 100 \mathrm{ml}$.

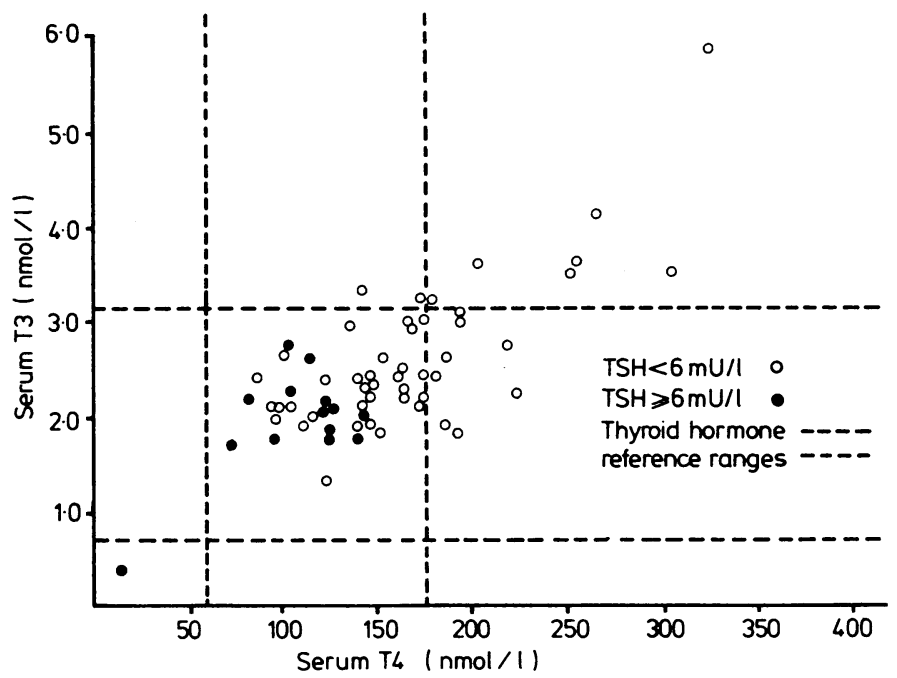

FIG 2-Relation of triiodothyronine (T3) concentrations with thyroxine (T4) concentrations in hypothyroid children.

Conversion: SI to traditional units-Triiodothyronine: $1 \mathrm{nmol} / \mathrm{l} \approx 0.65 \mathrm{ng} / \mathrm{ml}$. Thyroxine: $1 \mathrm{nmol} / \mathrm{l} \approx 0.08 \mu \mathrm{g} / 100 \mathrm{ml}$

at follow up. Previous outpatient measurements of T4 or protein bound iodine had been below the normal range in only four children but had been above normal on at least one previous occasion in $62 \%$.

\section{Treatment}

Figure 3 shows the thyroxine dosage expressed as $\mu \mathrm{g} / \mathrm{kg}$ body weight together with the recommended doses at different ages ${ }^{3}$ (MRC Register of Children with Congenital Hypothyroidism, Institute of Child Health, 30 Guilford Street, London WCIN 1EH). The mean total dose was $172 \cdot 3$

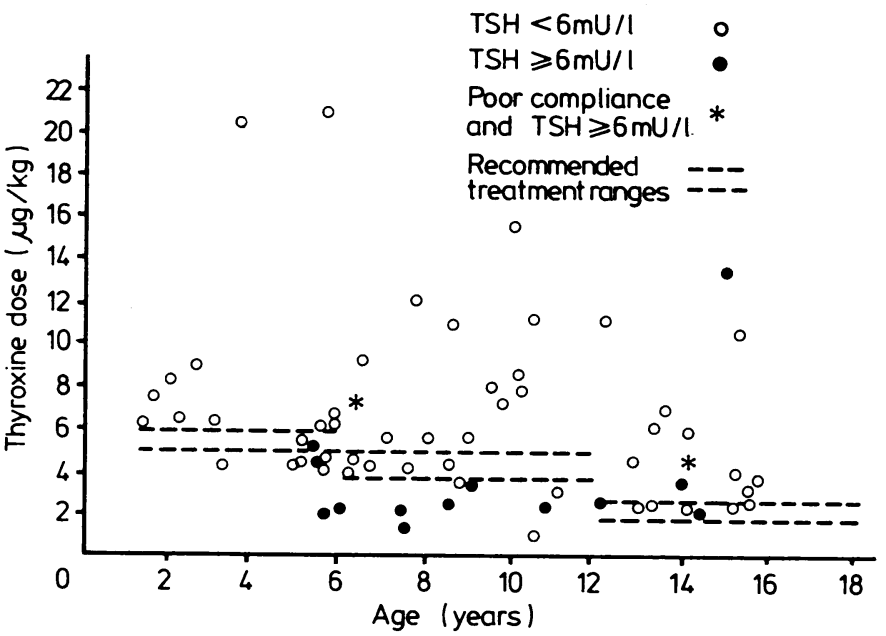

FIG 3-Thyroxine treatment doses/ $\mathrm{kg}$ body weight in hypothyroid children

(119.4) $\mu \mathrm{g}$ and the mean dose $/ \mathrm{kg} 4 \cdot 5(2 \cdot 2) \mu \mathrm{g}$. Expressed as $\mu \mathrm{g} / \mathrm{m}^{2}$ surface area the mean dose was $172.6(104 \cdot 1) \mu \mathrm{g}$. There was a significant correlation between the thyroxine dose and the T3 and T 4 concentrations $(p<0 \cdot 001)$ and the TSH value $(p<0 \cdot 05)$. Most of the children with serum TSH concentrations of $\geqslant 6 \mathrm{mU} / 1$ were being prescribed thyroxine at or below the lowest recommended limit (fig 3). Parents of the two older children with raised TSH values who were having treatment above the recommended range admitted to poor compliance, forgetting treatment more than once a week. TSH was adequately suppressed (excluding patients who admitted poor compliance) when the thyroxine dose was $100-125 \mu \mathrm{g} / \mathrm{m}^{2}$ (fig 4 ).

About $80 \%$ of all children who had serum T 4 or T 3 concentrations above the normal range were receiving doses per kilogram in excess of those recommended and often more than $150 \mu \mathrm{g} / \mathrm{m}^{2}$ (fig 4). 


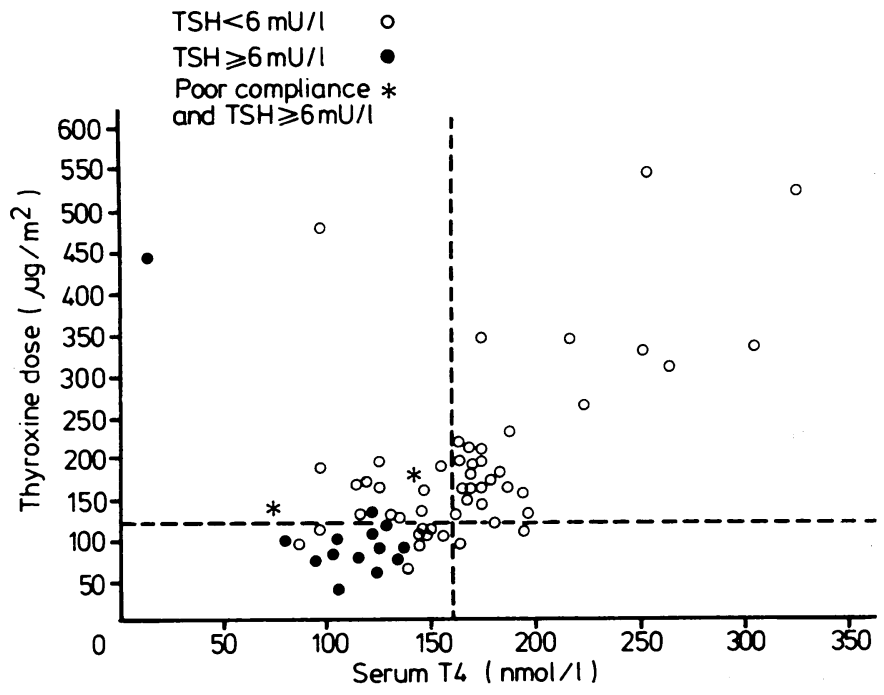

FIG 4-Thyroxine (T4) concentrations in relation to thyroxine dose $/ \mathrm{m}^{2}$ in hypothyroid children.

Conversion: SI to traditional units-Thyroxine: $1 \mathrm{nmol} / \mathrm{l} \approx 0.08 \mu \mathrm{g} / 100 \mathrm{ml}$.

\section{ADULTS}

\section{Biochemical}

The mean T4 concentration of 42 hypothyroid adults was $117 \cdot 0(42 \cdot 2)$ $\mathrm{nmol} / \mathrm{l}(9 \cdot 1(3 \cdot 3) \mu \mathrm{g} / 100 \mathrm{ml})$. This was significantly lower than in the hypothyroid children $(p<0.001)$. There was no difference with sex. Three of the T4 values were below the normal range $(60-150 \mathrm{nmol} / \mathrm{l} ; 4 \cdot 7$ $11.7 \mu \mathrm{g} / 100 \mathrm{ml}$ ) and seven were above it. Eleven women and six men $(41 \%)$ had TSH concentrations of $\geqslant 6 \mathrm{mU} / \mathrm{l}$. The mean T4 value of these was $87.6(30.2) \mathrm{nmol} / \mathrm{l}(6.8(2.3) \mu \mathrm{g} / 100 \mathrm{ml})$, and of those with a normal TSH concentration it was $135.4(38 \cdot 6) \mathrm{nmol} / \mathrm{l}(10.5(3.0) \mu \mathrm{g} / 100 \mathrm{ml})$ $(\mathrm{p}<0.001)$.

The mean T3 concentration was $1.8(0.6) \mathrm{nmol} / \mathrm{l}(1 \cdot 2(0.4) \mathrm{ng} / \mathrm{ml})$. This was significantly lower than that of the children $(p<0.001)$. Only one patient had a T3 concentration above the normal range but five had concentrations below the normal range (fig 5). There were significant

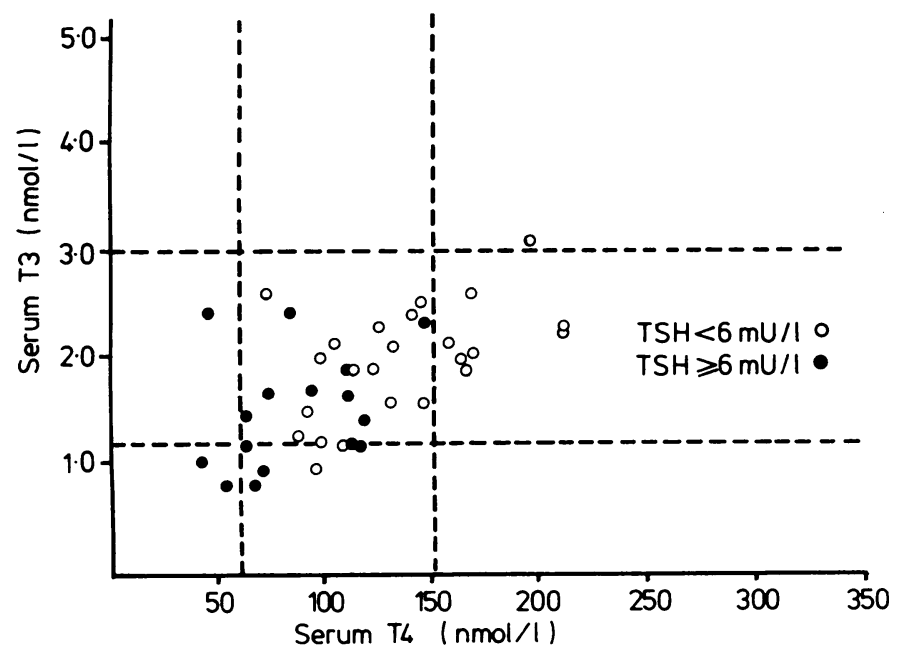

FIG 5-Relation of triiodothyronine (T3) concentrations with thyroxine (T4) concentrations in hypothyroid adults.

Conversion: SI to traditional units-Triiodothyronine: $1 \mathrm{nmol} / \mathrm{l} \approx 0.65 \mathrm{ng} / \mathrm{ml}$. Thyroxine: $1 \mathrm{nmol} / \mathrm{l} \approx 0.08 \mu \mathrm{g} / 100 \mathrm{ml}$

correlations between T3, T4, and TSH concentrations $(p<0.001)$. The T3 values of those with normal TSH concentrations were greater $(2 \cdot 0(0.5)$ $\mathrm{nmol} / \mathrm{l} ; 1 \cdot 3(0 \cdot 3) \mathrm{ng} / \mathrm{ml})$ than of those with a raised TSH concentration $(1 \cdot 6$ $(0.6) \mathrm{nmol} / \mathrm{l} ; 1.0(0.4) \mathrm{ng} / \mathrm{ml})(\mathrm{p}<0.05)$.

Most patients with a normal TSH concentration had serum T3 and T4 values in the upper half of the reference ranges (fig 5).

\section{Treatment}

The mean total thyroxine dose for the adults was $208 \cdot 0(77 \cdot 7) \mu \mathrm{g}$. When related to body size this was $3.3(1 \cdot 3) \mu \mathrm{g} / \mathrm{kg}$ or $125 \cdot 4(47 \cdot 1) \mu \mathrm{g} / \mathrm{m}^{2}$. The serum T 4 and $\mathrm{T} 3$ concentrations correlated with the total dose of thyroxine however expressed.

There was no relation between the dose of treatment and the TSH concentrations. Only three of the 17 adults with TSH values of $\geqslant 6 \mathrm{mU} / 1$ were receiving total doses of thyroxine of $<150 \mu \mathrm{g}$ but nine admitted to forgetting their treatment on one or more days a week. Excluding these, all but one adult with $\mathrm{T} 4$ concentrations in the upper half of the reference range and receiving over $100 \mu \mathrm{g} / \mathrm{m}^{2}$ had normal TSH values. Most of those with a $\mathrm{T} 4$ concentration above the normal range were receiving at least 150 $\mu \mathrm{g} / \mathrm{m}^{2}$. Three of the five patients with $\mathrm{T} 3$ concentrations below the normal range were receiving $<100 \mu \mathrm{g}$ thyroxine $/ \mathrm{m}^{2}$.

\section{T3/T4 INDEX}

In the children there was a highly significant correlation between the TSH concentration and T3/T4 index $(p<0.001)$, and in both children and adults the T3/T4 index was greater in those whose TSH value was $\geqslant 6 \mathrm{mU} / \mathrm{l}$ (children 19.7 (5.4) and adults $19 \cdot 2(9 \cdot 6)$ ) than in those with a normal TSH concentration (children $15 \cdot 9(3 \cdot 8)$, adults $15 \cdot 0(5 \cdot 0)$ ).

\section{CLINICAL SYMPTOMS AND SIGNS}

Few patients with biochemical evidence of undertreatment or overtreatment had any abnormal symptoms or signs.

The pulse rates of children correlated with their serum T4 concentrations $(p<0.05)$, and 13 of the 19 children with sweaty peripheries were receiving high doses of thyroxine $\left(>175 \mu \mathrm{g} / \mathrm{m}^{2}\right)$ and had a raised serum $\mathrm{T} 4$ value.

There was also an association $(p<0.05)$ between serum T3 and T4 concentrations and excessive energy and problems of concentration in the children. The mean T4 value in those with poor concentration $(n=37)$ was $167 \cdot 3(56 \cdot 2) \mathrm{nmol} / 1(13.0(4.4) \mu \mathrm{g} / 100 \mathrm{ml})$ compared with $142.4(43 \cdot 7)$ $\mathrm{nmol} / 1(11 \cdot 1(3 \cdot 4) \mu \mathrm{g} / 100 \mathrm{ml})$ in those without problems. The dose of thyroxine $/ \mathrm{m}^{2}$ in those with poor concentration was $196.9(122.6) \mu$ compared with $145.0(76.9) \mu \mathrm{g}$ in the rest. Multiple regression analysis ${ }^{8}$ confirmed that the concentration of serum thyroxine had an independent effect on the child's ability to concentrate but this was less powerful than the relation between intelligence quotient and concentration (concentration $=-0.584 \times \mathrm{IQ}+0.36 \times$ thyroxine value). Eighteen of the adults had problems with concentration but there was no association with the treatment doses.

There were no children with major clinical signs or symptoms of hypothyroidism, but five adults had acroparaesthesiae and four dry skin. Both of these symptoms correlated with serum TSH concentrations $(\mathrm{p}<0.05)$.

\section{BONE AGE}

Bone age was significantly more retarded in children most recently diagnosed $(\mathrm{p}<0.001)$ and in those who had been treated for more than two years whose TSH concentration was raised and who were receiving low dosage thyroxine.

In 17 children the bone ages were delayed by at least one year; five of these had been diagnosed within two years and were undergoing catch up growth. Half of the rest were receiving thyroxine doses below those recommended for age. Only one child treated for at least two years had a delay in bone age of greater than two years. Bone age was advanced between one and two years in 12 children and by more than two years in five. All were or had been receiving dosages over the recommendations for a long period, the latter group (three of whom were prepubertal) having been taking twice the recommended dose. The predicted adult heights of all these children fell at the lower end of the expected range for their parents' heights. The bone ages of most of those who were receiving the recommended dose of thyroxine were within one year of chronological age, except four with bone ages advanced by one to two years and four whose bone ages were delayed by one to two years.

\section{OTHER MEASURES}

Measurements of skinfold thickness were normal in all the hypothyroid patients. The height standard deviation scores in the children correlated 
inversely with age at diagnosis and directly with duration from diagnosis and midparental height $(\mathbf{p}<0 \cdot 05)$. The treatment dose also correlated with the score $(p<0.05)$ and with the difference between the child's score and the parental score $(p<0.05)$. Fourteen children had heights below the 10th centile. Four of these were children with a late onset and delayed diagnosis who had started treatment within the preceding two years and who probably had residual catch up growth potential. Four others had been longer on treatment but had delayed bone ages. The remaining six children had slightly delayed puberty or familial short stature. There were only two children whose heights were over the 97th centile, both of whom were receiving large doses of thyroxine.

There were no differences between the children's predicted adult heights and their expected adult heights (based on parental heights). The height centiles for the adult patients were all within the normal distribution for their sex.

Although all the children were being seen regularly in clinics, one third had had no growth measurements within the first few years after diagnosis, and height velocities were rarely recorded.

There was evidence of enamel hypoplasia of a variable degree in 30 of the children and residual signs of it in 12 of the adults. Twenty nine of the children and 24 of the adults had head circumferences above the 90th centile. There was no correlation of head circumference centiles with age at diagnosis in the children or adults. Half of the children had had no previous head circumference measurements recorded.

\section{Discussion}

Recent retrospective studies of congenital hypothyroidism have suggested that early screening and treatment should lead to normal intellectual development by protecting the brain from the damaging effects of thyroid deficiency in the first few months of life. Maximum benefit should occur if treatment is started before the age of 1 month, although even in this group severe deficiency in utero might lead to a degree of cerebellar damage with associated minor motor dysfunction. ${ }^{9 \cdot 11}$ Dussault $e t a l^{12}$ and the New England Congenital Hypothyroidism Collaborative ${ }^{1}$ in preliminary prospective assessments of screened populations have confirmed these predictions. For optimal results, however, correct dosage of replacement treatment is necessary. A number of errors are possible. An excessive dose may be prescribed, which, especially in early life, may lead to craniostenosis. ${ }^{1314}$ An inadequate dose may be the result of incorrect advice or poor compliance, and this may adversely affect intellectual development despite early detection.

Hulse et al reassessed a group of children with congenital hypothyroidism diagnosed by screening at 1 year of age, noting growth and biochemical measures in relation to treatment. ${ }^{\text {is }}$ Most patients had satisfactory growth but some had raised TSH concentrations. A persistently raised TSH value within the initial year after diagnosis despite adequate treatment does not necessarily imply hypothyroidism because of delayed return to normal of the hypothalamic thyroid axis. ${ }^{1617}$ Hulse et al, however, suggested that those who had thyroxine concentrations in the upper half of the reference range during the first year of life were less likely to have persistently raised TSH values and recommended regular biochemical monitoring and adjustment of treatment doses to achieve this.

In our study most children and adults who had normal TSH concentrations had T3 and T4 values above the midpoint of the reference range. Nevertheless, about half were receiving greater dosages of thyroxine than those now recommended. Many of these had raised serum $\mathrm{T} 4$ and sometimes $\mathrm{T} 3$ values, and some showed clinical signs of thyroxine excess or advanced bone age. On the other hand, several patients had raised TSH concentrations, indicating undertreatment. A similar tendency to inappropriate treatment has been shown recently by Hulse in a study in the south of England. "Most children between the ages of 5 and 12 years with raised TSH concentrations were prescribed less than the recommended doses of thyroxine. Most of the children over 12 with raised TSH values were receiving the recommended doses, though at the lower limit, and in these poor compliance may have been a problem.

Recommended doses of thyroxine ${ }^{3}$ (appendix) are expressed either as $\mu \mathrm{g} / \mathrm{day}$ or as $\mu \mathrm{g} / \mathrm{kg}$ body weight, both adjusted to age. Although there may be occasional discrepancies using either method, our findings support the recommendations except possibly at puberty. Sato et al, who looked at the threshold for TSH suppression by varying thyroxine doses in a group of children, also suggested that a higher dose might be indicated at puberty. ${ }^{16}$ An alternative method of determining dose is as $\mu \mathrm{g}$ thyroxine $/ \mathrm{m}^{2}$ surface area, and our results indicate that this may be useful. Guyda $^{3}$ and Rezvani and Di George ${ }^{18}$ in longitudinal studies have suggested $100 \mu \mathrm{g}$ thyroxine $/ \mathrm{m}^{2}$ to achieve biochemical normality and satisfactory growth. We found that biochemical results were kept mainly within the normal ranges and bone ages were least likely to be advanced or retarded with doses of thyroxine between 100 and $125 \mu \mathrm{g} / \mathrm{m}^{2}$.

Most of the adults in our study were receiving adequate doses of treatment ${ }^{19.21}$ but compliance was poor in many. Lower concentrations of thyroxine hormones in the older patients were compatible with the natural decline in values with age ${ }^{223}$ and the relatively lower doses of treatment required at these ages. ${ }^{24}$ Smaller doses in the elderly are necessary because of reduced thyroxine turnover. ${ }^{25}$

$\mathrm{T} 4$ concentrations correlated closely with $\mathrm{T} 3$ values both in the children and in the adults. Several children but only one adult had T3 values above the normal range. Macpherson et $a l^{26}$ and Murchison et $\mathrm{al}^{27}$ suggested that $\mathrm{T} 3$ concentrations were unlikely to rise above the normal range as a result of treatment despite raised $\mathrm{T} 4$ values, but our data agree with those of Capiferri and Evered $^{28}$ and Braverman et al, ${ }^{29}$ who found raised T3 concentrations in patients receiving high dosage replacement therapy. The lack of symptoms of hyperthyroidism in most patients with raised thyroxine concentrations may have been because production and clearance of $\mathrm{T} 3$ are different from those in thyrotoxicosis leading to lower circulating values. Desai et al have also found relatively few clinical signs in an overtreated group of hypothyroid children. ${ }^{30}$ Reverse T3 concentrations were raised in their patients and it was postulated that this was produced by a shunt of peripheral $\mathrm{T} 4$ metabolism from an activating to an inactivating pathway, preventing raised $\mathrm{T} 3$ values and clinical problems.

Some children in this study with raised T4 and T3 concentrations were overactive and had poor concentration, although this effect could not easily be separated from the effect of intellectual problems. Nevertheless, this and the association of high treatment dosage with advanced bone age indicate a need to avoid overtreatment. Care should be taken with dosage, particularly as the active content of thyroxine tablets has been increased by $11 \%$ (British Pharmacopoeia, 1980).

Both T3 and T4 concentrations were lower in those patients with raised TSH values, and in these patients, both children and adults, the T3:T4 ratios were higher, unlike those in the study of Maeda et al. ${ }^{31}$ These higher ratios were probably caused by a continuing conversion of $\mathrm{T} 4$ to $\mathrm{T} 3$ in peripheral tissues. The relevance of this subclinical hypothyroidism shown by raised TSH values is uncertain. Nevertheless, as there were associations of raised TSH concentrations and treatment dosage with bone age and height standard deviation scores in the children and with clinical symptoms of acroparaesthesia and dry skin in the adults they may have been clinically relevant. There is a possibility of cardiac problems ${ }^{32}$ and infertility ${ }^{33}$ with clinical hypothyroidism, so there clearly is a need for continued monitoring of patients receiving long term treatment. Children should be followed up regularly by paediatricians with careful recording of their thyroxine dose, thyroid biochemical state, and growth velocity. Adults should have occasional thyroid function tests done and be given advice about compliance either by their general practitioner or hospital physician. A system of registration and regular follow up similar to the Scottish automated register ${ }^{21}$ might be of value in this respect.

The height and head circumference centiles of the children were similar to those in Hulse's study. "Those children with heights below the third centile were mainly girls with late onset hypothyroidism and a delayed diagnosis who had begun treatment recently. Aynsley Green and Macfarlane in a study of short stature in the Oxford region have shown a similar delay in diagnosis in 
children with hypothyroidism. ${ }^{34}$ Most cases of congenital hypothyroidism should now be detected by neonatal biochemical screening but cases may still be missed. ${ }^{35}{ }^{36}$ Regular measurements of children in the community should reduce any delay in diagnosis of cases not detected by screening.

The outlook for patients with congenital hypothyroidism has been improved by early detection and continued clinical screening. The use of the age related treatment recommendations, regular assessment of growth including height velocity, and biochemical monitoring (using T4 and TSH and possibly free thyroid hormone measurements), with identification of inadequate compliance, should minimise the risks of complications and optimise the long term prognosis of patients with this condition.

We thank Dr D Cook and the staff of the Supra Regional Assay Laboratory; Dr M J Watson, Miss J Y Lawson, and the staff of the department of clinical biochemistry; and Dr R Lee, of the department of radiology, Royal Victoria Infirmary, Newcastle. We also thank Dr T Bird and the staff of the haematology department, Newcastle General Hospital, for the assessment of thyroid antibodies; Miss Vivien Male, statistician, Northern Area Health Authority; Mr S Ogston, statistician, Ninewells Hospital; and Dr D Macdonald, computer department, Dundee .University. We are grateful to the patients, parents, and referring specialists and primary care doctors. GJF was in receipt of a grant from the research committee of the Newcastle upon Tyne Area Health Authority (Teaching) and a grant from Pharmacia (GB) Ltd.

\section{Appendix}

Dosages of thyroxine recommended by first international conference on neonatal thyroid screening, Quebec, September 1979

\begin{tabular}{lcc}
\hline \multicolumn{1}{c}{ Age } & $\begin{array}{c}\text { Daily dose } \\
(\text { ug) }\end{array}$ & $\begin{array}{c}\text { Dose } / \mathbf{k g} \text { body weight } \\
(\text { (ug) }\end{array}$ \\
\hline$<6$ months & $25-50$ & $8-10$ \\
$6-12$ months & $50-75$ & $6-8$ \\
$1-5$ years & $75-100$ & $5-6$ \\
6-12 years & $100-150$ & $4-5$ \\
$>12$ years & $150-200$ & $2-3$ \\
\hline
\end{tabular}

\section{References}

1 New England Congenital Hypothyroidism Collaborative. Effects of neonatal screening for hypothyroidism: prevention of mental retardation by treatment before clinical manifestations. Lancet 1981 ;ii: $1095-8$

2 Scanlon MF, Weightman DR, Shale DJ, et al. Dopamine as a physiological regulator of thyrotrophin (TSH) secretion in normal man. Clin Endocrinol (Oxf) 1979;10:7-15.

3 Guyda HJ. Therapy of congenital hypothyroidism: evolution of biochemical parameters. In Guyda HJ. Therapy of congenital hypothyroidism: evolution of biochemical param
Burrow GN, ed. Neonatal thyroid screening. New York: Raven Press, 1980:247-61.

4 Tanner JM. Standards of normal growth: foetus into man. London: Open Books, 1978:167-205.
5 Tanner JM, Landt KW, Cameron N, Carter BS, Patel J. Prediction of adult height from height and bone age in childhood. Arch Dis Child 1983;58:767-76.

6 Tanner JM, Whitehouse RH. Revised standards for triceps and subscapular skinfolds in British children. Arch Dis Child 1975;50:142-5.

7 Tanner JM, Whitehouse RH. Growth and development charts. Castlemead Publications, Creaseys of Hertford Ltd, 1976.

8 Hull CH, Nie NH. SPSS (second edition)/SPSS update 7-9. New York: McGraw-Hill Book Company, 1975/1981.

9 Macfaul R, Dorner S, Brett EM, Grant DB. Neurological abnormalities in patients treated for hypothyroidism from early life. Arch Dis Child 1978;53:611-9.

10 Birrell J, Frost GJ, Parkin JM. The development of children with congenital hypothyroidism. Dev Med Child Neurol 1983;25:502-11.

11 Hulse JA. Outcome for congenital hypothyroidism. Arch Dis Child 1984;59:23-30

12 Dussault JH, Letarte J, Glorieux J, Morissette J, Guyda H. Psychological development of hypothyroid infants at age 12 and 18 months: experience after neonatal screening. In: Neonatal thyroid screening. New York: Raven Press, 1980:271-6.

13 Penfold JL, Simpson DA. Premature craniosynostosis-a complication of thyroid replacement therapy. 7 Pediatr 1975;86:360-3.

14 Weichsel ME Jr. Thyroid hormone replacement therapy in the perinatal period: neurological considerations. $\mathcal{F}$ Pediatr 1978:90:1035-8.

15 Hulse JA, Grant DB, Jackson D, Clayton BE. Growth, development, and reassessment of hypothyroid infants diagnosed by screening. Br Med $\mathcal{F}$ 1982;284:1435-7.

16 Sato T, Suzuki Y, Taketani T, Ishiguro K, Nakajima H. Age-related change in pituitary threshold for TSH release during thyroxine replacement therapy for cretinism. $\mathcal{J}$ Clin Endocrinol Metab 1977;44:553-9.

17 Schulz RM, Glassman MS, MacGillivray MH. Elevated threshold for thyrotrophin suppression in congenital hypothyroidism. Am $\mathcal{f}$ Dis Child 1980;134:19-20.

18 Rezvani I, Di George AM. Reassessment of the daily dose of oral thyroxine for replacement therapy in hypothyroid children. I Pediatr 1977;90:291-6.

19 Evered DC, Young ET, Ormstone BJ, Menzies R, Smith PA, Hall R. A reappraisal of thyroxine therapy. Br Med $\mathcal{J}$ 1973;iii:131-4.

20 Stock JM, Surks MI, Oppenheimer JH. Replacement dosage of L-thyroxine in hypothyroidism. N Engl F Med 1974;290:530-3.

21 Scottish Automated Follow-up Register Group. Thyroxine replacement therapy: prescribing patterns and problems in 2710 patients. $\mathrm{Br}$ Med $\mathcal{F} 1980 ; 281: 969-71$.

22 Corcoran JM, Eastman CJ, Carter JN, Lazarus L. Circulating thyroid hormone levels in corcoran JM, Eastman CJ, Carter JN, Latdren. Arch Dis Child 1977;52:716-20.
child

23 Vanderschueren-Lodeweyckx M, Eggermont E, Eeckels R. In vitro thyroid function tests: methodology and normal values in paediatrics. Acta Paediatrica Belgica 1981;34:121-41.

24 Rosenbaum RL, Barzel US. Levothyroxine replacement dose for primary hypothyroidism decreases with age. Ann Intern Med 1982;96:53-5.

25 Oddie TH, Meade JH Jr, Fisher DA. An analysis of published data on thyroxine turnover in human subjects. Fournal of Clinical Endocrinology 1966;26:425-37.

26 Macpherson JN, Isles TE, Peden NR, Crooks J. Importance of thyroxine in suppressing secretion of thyroid stimulating hormone. Br Med F 1982;284:1479.

27 Murchison LE, Chesters MI, Bewsher PD. Serum thyroid hormone levels in patients on thyroxine replacement therapy. Horm Metab Res 1976;8:324-5.

28 Capiferri R, Evered D. Investigation and treatment of hypothyroidism. Clin Endocrinol Metab 1979;8:39-48.

29 Braverman LE, Ingbar SH, Sterung $\mathrm{K}$. Conversion of thyroxine (T4) to triiodothyronine (T3) in athyreotic human subjects. $\mathcal{F}$ Clin Invest 1970;49:855-64.

30 Desai M, Irani AJ, Patil K, Pandya CS. The importance of reverse triiodothvronine in hypothyroid children on replacement treatment. Arch Dis Child 1984;59:30-5.

31 Maeda M, Kuzuya N, Masuyama Y, et al. Changes in serum triiodothyronine, thyroxine and thyrotrophin during treatment with thyroxine in severe primary hypothyroidism. $\mathcal{J}$ Clin Endocrinol Metab 1976;43:10-17

32 Hall R, Scanlon MF. Hypothyroidism: clinical features and complications. Clin Endocrinol Metab 1979;8:29-38.

33 Bohnet HG, Fielder K, Leidenberger FA. Hypothyroidism and infertility. Lancet 1981;8:1278.

34 Aynsley Green A, Macfarlane JA. Method for the earlier recognition of abnormal stature. Arch Dis Child 1983;58:535-7.

35 Mitchell ML, Larsen PR. Screening for congenital hypothyroidism in New England using the T4-TSH strategy. In: Neonatal thyroid screening. New York: Raven Press, 1980:95-105.

36 Murphy $\mathrm{W}_{\mathrm{H}} \mathrm{H}$. Panel and general discussion: optimal screening and recall procedures. In: Neonatal thyroid screening. New York: Raven Press, 1980:213-24.

(Accepted 8 fanuary 1985)
Routine immunisation against mumps is recommended in the United States. Why is it not recommended in Britain?

Immunisation with a live attenuated mumps vaccine is effective and not associated with an increased incidence of severe adverse reactions. Its routine use in the second year of life, combined with measles and rubella vaccines, has led to a $98 \%$ reduction in reported mumps in the United States ${ }^{1}$ together with a similar decline in its mortality and its most severe complication of encephalitis. ${ }^{2}$ It is estimated to be cost effective at a ratio of 7:1 for the reported incidence and 39:1 for the estimated actual incidence of mumps. ${ }^{3}$ A nationwide survey in $1982-3$ showed that $95 \%$ of United States school entrants had been immunised against mumps. ${ }^{2}$ Undoubtedly routine immunisation would be equally effective in Britain if similar levels of uptake were achieved. Experience with measles vaccination in Britain, however, where the uptake remains poor at $50-60 \%$ and yet the preventable morbidity and mortality is greater than with mumps, suggests that high levels of uptake, even with a combined measles and mumps vaccine, would not be achieved without major promotional campaigns and greater enthusiasm from medical and paramedical workers. High rates might not even be obtained unless immunisation became a necessary requirement for school entry, as occurs in many states in the United States.

A similar level of uptake of mumps vaccine to that of measles at present would still protect those who had received it, but would reduce the number of those susceptible and thus reduce wild virus circulation. This would almost certainly lead to an increase in the average age at which mumps is contracted, although the absolute numbers affected at any age may still decrease. The severe complications are more frequent in older children and adults. This would reverse the apparent natural trend at present for mumps in Britain to occur in a milder form at an earlier age. ${ }^{45}$ Thus doubt still exists in Britain regarding a policy for introducing routine mumps immunisation. — GLYN R WILliams, lecturer in infectious diseases, Glasgow.

Centers for disease control. Mumps-United States, 1983-84. MMWR 1984;33:533-5.

2 Centers for disease control. Mumps-United States, 1980-83. MMWR 1983;32:545-7.

3 Koplan JP, Preblud SR. A benefit-cost analysis of mumps vaccine. Am $\mathcal{F}$ Dis Child 1982;136:362-4.

4 Galbraith NS, Young SEJ, Pusey JJ, Crombie DL, Sparks JP. Mumps surveillance in England and Wales 1962-81. Lancet 1984; ;:91-4.

5 Donaghy M. Epidemiology of mumps in Scotland. Communicable Diseases Scotland Weekly Repor 1984;84/42:xi-xvii. 